\title{
MODAL SOSIAL USAHAWAN PENDATANG DI KABUPATEN TAKALAR PROVINSI SULAWESI SELATAN
}

\author{
Muhammad Faisal \\ Dosen Institut Pemerintahan Dalam Negeri (IPDN) Kampus Sulawesi Selatan \\ E-mail : faisalmile69@gmail.com
}

\begin{abstract}
ABSTRAK. Permasalahan dalam penelitian ini adalah bagaimana nilai dan norma yang dianut oleh usahawan pendatang di balik modal sosial yang mereka miliki. Sehingga penelitian ini bertujuan untuk mendapatkan keterangan ilmiah tentang nilai dan norma yang dianut oleh usahawan pendatang di Kabupaten Takalar Provinsi Sulawesi Selatan. Penelitian ini menggunakan pendekatan kualitatif dengan usahawan pendatang sebagai informan. Secara kualitatif hasil penelitian ini menjelaskkan bahwa bagi usahawan pendatang Bugis, budaya siri', pesan leluhur, agama, dan pengejaran status sosial telah menjadi spirit utama mereka dalam bekerja. Usahawan pendatang Bali memulai usahanya dengan konsep menanam budi yaitu memperbaiki hubungan baik dengan sesama manusia menjadi sumber motivasi utama dalam berusaha. Menanam budi terhadap sesama manusia, alam, dan Tuhan adalah sumber spirit mereka dalam berusaha karena menganggap bahwa usaha adalah karma. Pada usahawan pendatang Jawa dengan sikap tradisionalnya dalam berusaha didasari oleh keyakinannya bahwa orang harus hidup dalam persekutuan mesra dengan alam dan mengutamakan keselarasan dan kesabaran. Usahawan pendatang Cina, kepercayaan terhadap leluhur dan keyakinannya bahwa kalau usaha dikelola dengan sungguh-sungguh akan berhasil menjadi spirit mereka dalam berusaha. Usahawan pendatang Jawa, Cina, Bali dan Bugis, mereka memiliki unsur-unsur modal sosial seperti saling percaya, hubungan timbal-balik, dan jaringan kerja yang luas.
\end{abstract}

Kata Kunci: modal sosial, nilai, norma, usahawan pendatang.

\section{SOCIAL CAPITAL IMMIGRANT ENTREPRENEURS IN TAKALAR SOUTH SULAWESI PROVINCE}

ABSTRACT. The problem this research how the values and norms adopted by immigrant entrepreneurs behind the social capital they have. Thus this study aims obtain scientific information about values and norms adopted by immigrant entrepreneurs in Takalar South Sulawesi province. This study used qualitative approach with immigrant entrepreneurs as informant. Qualitatively the results study acknowledges that businessman Bugis migrants, culture siri ', ancestral message, religion, and the pursuit of social status has become the main spirit in their work. Bali immigrant entrepreneurs start their business the concept plant cultivation improve relationships with fellow human beings become the main source of motivation in trying. Planting favor fellow human beings, nature, and God the source their spirit trying because they think business is karma. In Javanese migrants businessman with traditional attitudes the attempt based the belief people should live in intimate communion with nature and give priority to harmony and patience. Chinese immigrant entrepreneurs, confidence in ancestor and his belief the business is managed in earnest will prosper into their spirit the attempt. Java immigrant entrepreneurs, China, Bali and Bugis, they have elements of social capital such as trust, reciprocal relationships, and extensive networks.

Key words: social capital, values, norms, entrepreneurial immigrants.

\section{PENDAHULUAN}

Studi tentang keberadaan usahawan pendatang di beberapa daerah telah melahirkan sejumlah hasil penelitian. Beberapa hasil penelitian itu menunjukkan bahwa kebanyakan pendatang berada pada kelompok umur muda dan produktif, selain itu digambarkan pula bahwa pendapatan (remittances) pendatang di daerah tujuan banyak dikirim ke daerah asal (Faisal, 2005: Tantu, 1982; 1988; Mantra, 1978; Abustam. 1975: 1989).

Selain itu, modal sosial dari pendatang juga mendapat perhatian. Para peneliti berfokus pada unsurunsur modal sosial seperti kepercayaan (trust), jaringan kerja (networking), norma, nilai, resiprocity, dan mereka menemukan adanya hubungan modal sosial yang dimiliki para usahawan dengan pencapaian tujuan- tujuan hidup terutama tujuan ekonomi, (Muspida, 2007; Rivai; 2007, Fukuyama, 1999, 2000, 2007).

Munculnya konsep usahawan pendatang, pada hakikatnya merupakan suatu refleksi perbedaan pertumbuhan dan ketidakmerataan hasil-hasil pem bangunan antara suatu daerah dengan daerah lain. Ketidak seimbangan kekuatan dan potensi ekonomi antara daerah tersebut menyebabkan terjadinya gerak penduduk. Keberadaan usahawan pendatang di suatu daerah adalah hal yang wajar sebagai reaksi dari perkembangan sosial ekonomi.

Fenomena perkembangan ekonomi di Kabupaten Takalar yang relatif stagnan, mengindikasikan belum maksimalnya pemanfaatan modal sosial yang dimiliki oleh masyarakat lokal dan usahawan pendatang. Padahal, menurut Hasbullah (2006) modal sosial diyakini sebagai 
salah satu komponen utama dalam menggerakkan kebersamaan, mobilitas ide, kesalingpercayaan dan kesaling menguntungkan untuk mencapai kemajuan usaha bersama. Hubungannya dengan modal sosial, Putnam (2000) merinci modal sosial sebagai nilainilai, norma-norma, dan kepercayaan yang dapat mempermudah masyarakat bekerjasama secara efektif dan berkoordinasi untuk mencapai tujuan. Dimensi modal sosial tumbuh di dalam suatu masyarakat yang di dalamnya berisi nilai dan norma serta pola-pola interaksi sosial dalam mengatur kehidupan keseharian anggotanya. Oleh karena itu, Adler dan Kwon (2000) menyatakan, dimensi modal sosial merupakan gambaran dan keterikatan internal yang mewarnai struktur kolektif dan memberikan kohesifitas dan keuntungankeuntungan bersama dan proses dinamika sosial yang terjadi di dalam masyarakat. Sementara itu, menurut Sukoco dan Herwan A Muchyi (2015) keuntungankeuntungan itu tidaklah selalu dalam bentuk uang misalnya tersedianya waktu untuk libur dari pekerjaan atau bekerja yang lebih santai.

Dimensi modal sosial menggambarkan segala sesuatu yang membuat masyarakat bersekutu untuk mencapai tujuan bersama atas dasar kebersamaan, serta di dalamnya diikat oleh nilai-nilai dan norma-norma yang tumbuh dan dipatuhi (Dasgupta dan Serageldin, 1999). Namun demikian Fukuyama (1995, 2000, 2007) dengan tegas menyatakan, belum tentu norma-norma dan nilainilai bersama yang dipedomani sebagai acuan bersikap, bertindak, dan bertingkah-laku itu otomatis menjadi modal sosial, akan tetapi hanyalah norma-norma dan nilai-nilai bersama yang dibangkitkan oleh kepercayaan (trust). Dimana trust ini adalah merupakan harapanharapan terhadap keteraturan, kejujuran, dan perilaku kooperatif yang muncul dari dalam sebuah komunitas masyarakat yang didasarkan pada norma-norma yang dianut bersama oleh para anggotanya. Norma-norma tersebut bisa berisi pemyataan-pemyataan yang berkisar pada nilai-nilai luhur (kebajikan) dan keadilan. Rasa kepercayaan ini oleh Granovetter (1985) disebut sebagai keterlekatan ekonomi.

Modal sosial lebih menekankan pada potensi kelompok dan pola-pola hubungan antara individu dalam suatu kelompok dan antar kelompok dengan ruang perhatian pada jaringan sosial, norma, nilai, dan kepercayaan antara sesama yang lahir dari anggota kelompok dan menjadi norma kelompok.

Berdasarkan fenomena perkembangan usaha di Kabupaten Takalar yang relatif stagnan tersebut, terutama usaha-usaha di sektor informal, di balik kiprah para usahawan pendatang, maka modal sosial yang dimiliki oleh usahawan pendatang tersebut menempati posisi yang penting untuk dikaji. Oleh karena itu, pertanyaan pokok yang ingin dijawab pada tulisan ini adalah bagaimana nilai dan norma yang dianut oleh usahawan pendatang melatari modal sosial mereka?

\section{METODE}

Berangkat dari pertanyaan pokok penelitian ini, menunjukkan bahwa penekanan studi diarahkan kepada pemahaman bahwa nilai dan norma yang dianut mengondisikan modal sosial dari usahawan pendatang dan hal ini dilihat dari biografi mereka termasuk digali dari pengalaman mereka di dalam melakukan usaha ekonomi. Olehnya itu jenis penelitian yang dilakukan adalah kualitatif. Tradisi fenomenologi adalah yang paling tepat digunakan sebagai pendekatan utama di dalam penelitian ini, sedangkan tradisi biografi dijadikan sebagai pendekatan sekunder.

Pendekatan melalui tradisi fenomenologi dipilih karena tradisi ini berfokus pada pemahaman hakikat pengalaman tentang sebuah fenomenologi. Ini sesuai dengan fokus utama dari penelitian ini yaitu memahami esensi dari pengalaman tentang fenomena pemikiran subjektif atas makna-makna. Selain itu, hubungan antara peneliti dan subjek inkuiri saling memengaruhi, keduanya sulit dipisahkan, bahwa untuk menggali pikiran, dan perubahan pikiran subjek inkuiri, khususnya di dalam menginterpretasi hal-hal konkrit ke dalam gagasan-gagasan yang kemudian mengondisikan modal sosial dari para usahawan pendatang dibutuhkan dialogdialog mendalam antara peneliti dan subjek inkuiri. Sedangkan tradisi biografi dipilih sebagai pendekatan sekunder dari penelitian ini, terutama untuk menggali kehidupan dan pengalaman individu berkaitan dengan kegiatan pengembangan usaha yang menggambarkan modal sosial para usahawan.

Wawancara mendalam digunakan untuk menyelami bagaimana nilai dan norma yang dianut para usahawan pendatang itu mengondisikan karakteristik modal sosial baik yang bonding maupun yang bridging termasuk untuk menghimpun informasi dari para informan penelitian. Informasi tersebut ditopang pula dengan observasi terhadap lokasi-lokasi usaha termasuk bagaimana mereka mengelola usaha. Dari observasi yang dilakukan terhadap seluruh kejadian dilakukan pencatatan lapangan terutama berkaitan dengan strategi-strategi mereka dalam mengelola usaha, interaksi sosial yang berlangsung, termasuk bagaimana pemanfaatan terhadap aspek ruang dan waktu. Untuk menjaring data tersebut dipadukan pula dengan teknik dokumentasi. Analisis data kualitatif dalam penelitian ini berlangsung bersamaan dengan proses pengumpulan data. Di antaranya adalah melalui tiga tahap model air, yaitu reduksi data, penyajian data, dan verifikasi. Selain itu, peneliti juga melakukan pengabsahan data melalui triangulasi sumber, waktu dan metode.

Beberapa konsep dalam tulisan ini didefinisikan sebagai berikut:

(1) Usahawan pendatang adalah mereka yang melakukan usaha ekonomi baik usaha kecil maupun besar yang sudah mengelola usaha lebih 
dari 10 tahun dan mereka pada awalnya berasal dari berbagai suku seperti Jawa, Bali, keturunan Cina, dan Bugis serta berdomisili di Kabupaten Takalar sudah lebih dari 10 tahun.

(2) Modal sosial adalah ciri atau karakter yang mewarnai para usahawan pendatang dalam membangun hubungan sosial terkait pengembangan usaha seperti mutual trust, resiprocity, dan networking.

\section{HASIL DAN PEMBAHASAN}

Bagian ini mengelaborasi nilai dan norma yang dianut oleh usahawan pendatang yang melatari modal sosial mereka. Usahawan pendatang Jawa dalam melakukan usaha ekonomi dikenal dengan sangat sopan dan menghargai orang lain. Bahkan dalam berinteraksi dengan masyarakat lokal mereka cenderung menundukkan kepala sebagai wujud dari penghargaan mereka kepada orang lain yang ditemani berinteraksi. Mereka juga tidak memilih-milih pekerjaan di daerah perantauan yang penting mereka mendapat pekerjaan. Secara sosiologik dapat diinterpretasi bahwa usahawan pendatang Jawa dalam melakukan usaha ekonomi, dipengaruhi oleh suatu nilai dan norma yang menurutnya berlaku umum di masyarakat. Sopan santun merupakan cara untuk menghargai orang lain, siapa saja yang dengan mereka itu berinteraksi. Hubungan dengan sesama harus dijaga supaya tetap harmonis. Selain itu, mereka berupaya untuk memberikan pelayanan yang terbaik kepada pelanggannya dengan menjaga kualitas dagangannya. Menjaga keharmonisan dengan sesama manusia melahirkan kepercayaan (trust) yang dapat berdampak kepada luasnya jaringan kerja (networking).

Usahawan pendatang Jawa dalam melakukan usaha ekonomi diwarnai oleh nilai-nilai moral budaya Jawa, salah satunya adalah apa yang disebut sebagai harmonis. Karakteristik inti dari pandangan harmonis ini adalah menciptakan dan menjaga kesesuaian atau keselarasan hubungan antar sesama manusia, masyarakat dan dengan alam. Ketiganya merupakan satu sistem yang biasa disebut sebagai "pandangan dunia Jawa". Nilai pragmatis dari pandangan dunia Jawa ini adalah agar tercapai suatu keadaan psikis tertentu, seperti ketenangan, ketentraman, dan keseimbangan batin.

Norma lainnya yang turut mengondisikan modal sosial dari usahawan pendatang Jawa adalah norma agama. Usahawan pendatang Jawa dalam melakukan usaha ekonomi tampak tenang, dan bersabar dalam mengelola usahanya. Ini karena dipengaruhi oleh keyakinan terhadap hal-hal yang transenden. Hal yang transenden disini dimaknai sebagai sesuatu yang secara kualitas teratas atau di luar apa yang diberikan oleh pengalaman manusia. Mereka sangat memperhatikan ibadah sebagai wujud dari pelaksanaan agama. Bagi mereka, bekerja adalah sangat penting untuk dapat menghidupi keluarga, tetapi bekerja tidaklah cukup kalau tidak dibarengi dengan doa. Bekerja dan berdoa adalah sama-sama penting untuk mencapai kehidupan yang tenang seimbang lahir dan batin.

Selain itu, usahawan pendatang Jawa sangat memperhatikan pendidikan anak-anaknya. Pendidikan adalah sebuah investasi untuk masa depan keluarga mereka, untuk itu mereka berusaha dalam rangka pembiayaan sekolah bagi anak-anaknya. Mereka berpartisipasi secara pro aktif dengan memberikan sumbangan kepada pengembangan pesantren tempat anaknya belajar.

Menyangkut keluarga dan kekerabatan para usahawan Jawa berbeda dengan masyarakat lokal. Pola-pola sosiokultural yang teratur yang mengatur pelaksanaan perkawinan dan reproduksi itu, bagi usahawan Jawa tidak nampak secara berlebih-lebihan. Bagi mereka perkawinan antara sesama orang Jawa tidak terlalu banyak mengeluarkan biaya, yang terpenting bagi mereka adalah mahar yang menjadi hal yang wajib, tidak perlu dilaksanakan pesta besarbesaran sebagaimana pada kebiasaan dari masyarakat lokal. Bagi orang Jawa, yang lebih penting adalah menyiapkan modal usaha untuk digunakan membuka usaha sesudah kawin.

Bagi usahawan Jawa menganggap peralatan atau teknik yang dengannya manusia beradaptasi dengan lingkungan fisiknya itu sangat penting untuk mereka miliki. Mereka ingin membeli sepeda motor dan mobil untuk memperlancar dan mengembangkan usaha mereka serta memperluas jaringan kerja (networing). Demikian juga peralatan lain seperti pabrik penggilingan daging sangat penting untuk memperluas usaha ekonomi mereka. Dengan demikian dapat dikatakan bahwa keinginan untuk memperoleh peralatan yang dapat memudahkan pengelolaan usaha mereka juga turut mengondisikan terbentuknya etos kerja dan modal sosial mereka. Bagi usahawan pendatang Jawa juga sangat memberikan perhatian pada nilai-nilai bersama untuk berkumpul kembali dengan keluarga mereka. Sebagai perantau dalam waktu satu tahun atau lebih mereka selalu berkeinginan untuk pulang ke Jawa berkumpul dengan keluarga dan kerabat mereka. Untuk maksud tersebut mereka selalu menyisakan biaya pulang kampung dari hasil usaha mereka itu. Dengan demikian, dapat dianggap bahwa nilai untuk selalu bertemu dengan keluarga dekat juga mengondisikan usahawan pendatang Jawa dalam mengelola usaha mereka.

Usahawan keturuan Cina dalam melakukan usaha ekonomi, juga banyak dikondisikan oleh nilai dan norma yang mereka anut. Dalam mencari penghidupan orangorang Cina di Takalar lebih memilih untuk berdagang. Mereka mempunyai wawasan dan visi yang jauh ke depan. Usahawan keturunan Cina memandang pekerjaan sebagai tradisi keluarga. Pekerjaan sebagai pedagang merupakan warisan dari orang tuanya. Hal ini mengingatkan kita kepada tulisan Adam Smith (Heilbroner, 1994: 10) bahwa 
di Mesir Kuno, setiap orang diharuskan oleh agama untuk mengikuti pekerjaan ayahnya, dan harus membayar denda yang besar jika ingin mengganti pekerjaan. Demikian juga dalam masyarakat Barat sampai abad ke 15 atau 16, pewarisan pekerjaan juga merupakan faktor utama dalam menentukan pembagian kerja dalam masyarakat, seseorang yang dilahirkan pada keluarga petani atau pedagang biasanya akan mengikuti jejak orang tuanya (Heilbroner, 1994: 11). Ini menunjukkan bahwa tradisi mewarisi pekerjaan telah berlangsung lama di dunia, tidak hanya bagi usahawan pendatang Cina. Jadi dengan demikian nilai-nilai dalam keluarga sudah menjadi faktor stabilisasi dan mengikat dalam siklus masyarakat, dan menjamin bahwa pekerjaan-pekerjaan yang paling diperlukan oleh masyarakat akan terus berlangsung. Bagi usahawan keturunan Cina berpendapat bahwa dengan mewariskan pekerjaan ayah kepada anak maka keahlian dapat diwariskan secara turun-temurun. Itulah sebabnya usahawan pendatang Cina secara turun-temurun mewarisi pekerjaan orang tuanya.

Usahawan keturunan Cina dalam melakukan usaha ekonomi juga percaya kepada pesan-pesan dari leluhur mereka. Rupanya pesan leluhur memberikan nilai tersendiri kepada pengembangan usaha, yakni terpacu untuk membuka usaha sendiri melanjutkan usaha orang tua. Dengan membuka usaha sendiri berarti menjadi seorang Bos, bisa hidup lebih nyaman, memiliki kekuasaan, dan dapat membuat peraturan sendiri. Jika bisnisnya untung, maka keluarga dapat menikmati hasilnya dan sebaliknya jika merugi maka resiko itu akan menjadi cambuk untuk berupaya lebih giat lagi.

Usahawan Cina sangat yakin bahwa cepat atau lambat usaha dagang bisa mendatangkan keuntungan dan mereka bisa keluar dari impitan kemiskinan. Keyakinan yang kuat ini merupakan nilai yang membuat mereka bersemangat untuk berwirausaha. Nilai inilah yang mengondisikan etos kerja dan modal sosial dari para usahawan pendatang Cina.

Usahawan keturunan Cina dalam berdagang, mereka tidak mau kompromi, terutama menyangkut kualitas barang, untung, dan rugi. Prinsip usahawan Cina adalah "lebih baik mengambil untung sedikit, yang penting kualitas dan pelayanan yang baik". Makanya banyak masyarakat lokal yang sering datang berbelanja ke toko milik usahawan pendatang Cina tersebut. Sisi lain dalam kehidupan usahawan Cina adalah kepercayaannya terhadap dewa-dewa. Sebagai bentuk dari kepercayaan tersebut, mereka membakar lilin berwarna merah pada pagi sampai siang hari dengan maksud memanggil dewa-dewa yang akan membawakan rejeki. Mereka secara turun-temurun mengikuti tradisi nenek moyang. Dalam tradisi Cina, dewa tertua dan paling dihormati diangkat sebagai dewa penguasa langit. Kepercayaan ini mendorong mereka untuk mencapai kesejahteraan, kemakmuran, dan kebahagiaan hidup secara harmonis melalui penyembahan pada dewa-dewa dan roh-roh nenek moyangnya.
Selain itu, paham kekeluargaan usahawan Cina punya andil dalam kepercayaan yang memengaruhi bisnis mereka. Dalam keluarga Cina, pendidikan tentang berdagang secara otomatis mereka turunkan kepada anak-anaknya. Seluruh anggota keluarga Cina turut bekerja. Tidak ada keluarga Cina yang tidak produktif. Ini menunjukkan bahwa usahawan pendatang keturunan Cina sangat memperhatikan pendidikan bisnis bagi keluarga. Dengan keterlibatan anak-anak mereka dalam mengelola usaha berarti memberikan pengamalan dan pendidikan kepada anak sejak dini dalam berbisnis. Oleh karena itu, nampak bahwa keluarga bagi usahawan pendatang Cina menjadi semacam ideologi (familism). Dalam sistem sosial Cina, anak laki-laki adalah pewaris keturunan karena mereka akan mewarisi harta dan kekayaan keluarga. Makanya, anak laki-laki memiliki tanggung jawab yang besar dan harus mampu menjaga martabat dan nama baik keluarga. Mereka harus berusaha keras mengharumkan dan memuliakan keturunannya. Beberapa poin penting yang dapat disarikan dari uraian di atas sekaitan dengan modal sosial usahawan keturunan Cina dibalik nilai dan norma yang mereka anut adalah sebagai berikut:

(1) Dalam sistem keluarga usahawan Cina, etos kerja telah ditanamkan kepada anak-anak mereka sejak kecil. Bagi usahawan Cina, kerja dihubungkan dengan sekumpulan nilai kompleks yang mencakup pengorbanan diri, hemat, dan rasa percaya yang dipandang sebagai dasar terkumpulnya kekayaan.

(2) Etos kerja para usahawan Cina berorientasi kelompok. Setiap individu berpartisipasi dalam meningkatkan kesejahteraan keluarga, yang menjadi basis utama bagi kesejahteraan masyarakat.

(3) Usahawan pendatang keturunan Cina bekerja keras untuk mendapatkan imbalan materi. Kemakmuran dan kenyamanan dalam usia lanjut merupakan tujuan mereka dalam berusaha. Jadi mereka memandang kerja sebagai orientasi nilai instrumental.

Usahawan pendatang Bali dalam melakukan usaha ekonomi, juga dipengaruhi oleh nilai dan norma yang mereka anut. Demikian juga norma agama yang berisi kepercayaan dan nilai bersama yang bersinggungan dengan keyakinan akan adanya kekuatan dan kekuasaan sesuatu yang bersifat supernatural. Agama merupakan salah satu sumber motivasi bagi usahawan Bali dalam melakukan pekerjaan. Inti ajaran dari agama Hindu bagi orang Bali pada umumnya mengenal dalam bentuk konsep Trimurti. Trimurti ini mempunyai tiga wujud atau manifestasi yaitu wujud Brahma, yang menciptakan, wujud Wisnu, yang melindungi serta memelihara, dan wujud Siwa, yang melebur segala yang ada. Manifestasi dari keyakinan beragama ini adalah mereka memandang bahwa kerja adalah sesuatu yang luhur, adanya buah dari setiap perbuatan (karma-pala). Orientasi nilai kerja dari usahawan Bali sangat menarik dihubungkan dengan 
versi Kluckhonhn yang menjelaskan bahwa dalam setiap kebudayaan yang ada di dunia ini, terdapat lima masalah dasar yang sangat menentukan dan memengaruhi orientasi nilai budaya manusia. Masalah dasar tersebut, yakni: (1) masalah hakikat dan sifat hidup, (2) hakikat karya/kerja manusia, (3) hakikat kedudukan manusia dalam ruang dan waktu, (4) hakikat hubungan manusia dengan alam, (5) hakikat hubungan manusia dengan manusia. Berkaitan dengan hal tersebut, maka spirit usaha bagi usahawan pendatang Bali dapat diketahui melalui beberapa aspek. Pertama, orientasi nilai di mana usahawan Bali memandang bahwa karya atau kerja pada hakikatnya bertujuan untuk mencari nafkah untuk dapat hidup, artinya bahwa kerja tidak bisa dilepas-pisahkan dengan kehidupan manusia. Karena itu, keberhasilan dalam melakukan usaha ekonomi sangat ditentukan oleh kesungguhan seseorang dalam mencapai tujuan. Kedua, pengaruh orientasi nilai hubungan manusia dengan manusia. Sebagaimana masyarakat pada umumnya, usahawan Bali juga mementingkan hubungan manusia dengan manusia.

Hubungan manusia dengan manusia bagi usahawan Bali tampil dalam sikap sopan santun, menghargai, dan membantu orang lain. Tidak terkecuali pada bulan Ramadhan, usahawan pendatang Bali sering memberikan bantuan ke mesjid untuk dipakai berbuka puasa. Dengan istilah yang digunakan "investasi moral", mereka meyakini bahwa kelak akan memberikan manfaat yang besar terhadap keberlangsungan usaha yang dikembangkan di Kabupaten Takalar.

Ketiga, pengaruh orientasi nilai hubungan manusia dengan alam. Bagi usahawan pendatang Bali juga beranggapan bahwa alam sangat berpengaruh kepada kehidupan manusia. Makanya satu dari komponen pedoman hidup orang Bali yang disebut sebagai Trihita Karana adalah menjaga hubungan baik antara manusia dengan alam. Di satu sisi, alam dapat mendatangkan rezeki bagi manusia, tetapi di sisi lain sumber rezeki itu dapat berubah menjadi bencana atau malapetaka jika ternyata manusia bertindak semberono terhadapnya. Dengan itu, Usahawan Bali mempunyai orientasi kosmologi. Orientasi kosmologi ini merupakan manifestasi yang tak henti-hentinya mereka mencari ketenteraman dan harmoni dalam hidup (Melalatoa, 1997: 108).

Usahawan pendatang Bali percaya bahwa kebahagiaan hidup di dunia apabila ada keselarasan atau dekat dengan alam. Hidup bahagia didapat kalau seseorang dapat mencium bau tanah, mendengar suara makhlukhidup, dan merasakan kekayaan yang berlimpah dari tanah, air, dan tumbuh-tumbuhan. Seperti yang dikemukakan oleh Anh (1984: 87) bahwa makrokosmos dan mikrokosmos saling berhubungan secara harmonis sempurna, sehingga sesuatu yang tercipta selaras dengan lingkungannya. Kesempurnaan di alam semesta ini merupakan kesatuan antara dua komponen dikotomik, yang berarti bahwa satu komponen tidak mungkin ada tanpa komponen yang lain. Kesemuanya ini merupakan bagian dari nilai dan norma yang turut melatari modal sosial dari usahawan Bali di Kabupaten Takalar dalam mengelola usaha. Dengan demikian, modal sosial dari usahawan pendatang Bali dibalik nilai dan norma yang mereka anut adalah: (1) berkaitan dengan makna kerja itu sendiri dan (2) dasar keberhasilan usaha. Berkaitan dengan yang pertama, maka usahawan pendatang Bali menganggap bahwa kerja adalah karma yang baik dan tidak bisa dilepas-pisahkan dari kehidupan manusia. Kerja tidak lain adalah ungkapan diri seseorang dan sekaligus menampakkan harga diri seseorang. Kaitannya dengan yang kedua, usahawan pendatang Bali menganggap keberhasilan dalam usaha ditentukan oleh beberapa faktor seperti kehendak Tuhan, hubungan manusia dengan manusia harus harmonis, dan juga harus menjaga hubungan harmonis antara manusia dengan alam.

Selanjutnya, nilai dan norma yang melatari modal sosial usahawan pendatang Bugis di Kabupaten Takalar. Salah satu nilai dan norma usahawan Bugis adalah bersikap dan bertutur kata yang santun kepada orang lain. Dengan begitu, mereka merasa akan diterima dengan baik oleh masyarakat di sekitarnya. Hal ini sejalan dengan asumsi bahwa untuk menjalankan aktivitas usaha apapun, tidak cukup kalau hanya memiliki modal finansial, akan tetapi sejumlah modal sosial menjadi syarat yang perlu untuk dimiliki terutama dalam menjalin kerjasama dengan pembeli atau pemakai.

Bertutur kata merupakan modal utama dalam pengembangan usaha dan bahkan menjadi penentu terjalin dan terciptanya unsur-unsur dari modal sosial seperti partisipasi, kerjasama, saling percaya, dan jaringan kerja (networking) yang luas. Strategi berkomunikasi menentukan apakah yang diajak berbicara menerima dengan baik atau malah sebaliknya. Demikian pula sikap dan tingkah laku merupakan penentu lahirnya keinginan dari pembeli. Oleh karenanya, dalam melakukan usaha ekonomi dari usahawan pendatang Bugis memiliki falsafah hidup dan pada gilirannya menjadikannya sebagai pandangan hidup (way of life) seperti sipakatau (memanusiakan manusia), dan sipakalebbi (saling memuliakan).

Pentingnya usaha dan kerja keras juga didapat dari pesan-pesan leluhur mereka seperti " "resopa temmangingi namallomo naletei pammase dewata" yang berarti hanya dengan kerja keras dan sungguhsungguh yang mendapat rahmat dari yang maha kuasa. Pesan leluhur yang lain seperti "aja mumaelo natunai sekke, naburuki labo" (jangan terhina oleh sifat kikir dan hancur oleh sifat boros). Pesan-pesan leluhur mereka sampai sekarang masih terpatri dalam jiwa mereka dan menjadi motivasi dalam melakukan usaha ekonomi. Makna dari pesan-pesan leluhur itu adalah bahwa dalam bekerja harus dikerjakan dengan penuh kesungguhan, 
tidak dengan asal kerja, karena hanya dengan kerja yang sungguh-sungguh yang akan mendapat restu dan berkah dari Tuhan. Demikian juga dalam hidup bermasyarakat harus pro aktif mencari solusi apabila terdapat masalahmasalah yang ingin dipecahkan secara bersama-sama, jangan berlaku kikir, dan perlu mempunyai perhitungan yang matang dalam mengelola usaha.

Norma lainnya yang tampak pada usahawan pendatang Bugis yang melatarimodal sosial merekaadalah siri'. Siri' bagi usahawan pendatang Bugis merupakan eksistensi sebagai manusia dalam kehidupannya dan bagi mereka yang tidak memiliki siri' dianggap tidak lebih hanya sebagai binatang.

Siri' merupakan konsep yang mencakup gagasan tentang harga diri dan rasa malu, sekaligus merupakan asal munculnya harga diri itu sendiri. Secara substantif siri' merupakan keinginan untuk berbuat kebajikan bagi diri dan bagi sesama manusia dalam meningkatkan harkat, martabat, dan kemanusiaan yang berintikan susila. Olehnya itu dapat dikatakan bahwa siri' telah menjadi sumber motivasi utama bagi usahawan Bugis dalam melakukan usaha. Dengan berusaha ekonomi, maka mereka berharap dapat menutupi siri' terhadap diri dan keluarganya. Siri' merupakan aktualisasi diri, dimana aktualisasi diri manusia pada gilirannya menghasilkan sarana-sarana hidup, dan secara tidak langsung memperlihatkan eksistensi materinya. Proses inilah sesungguhnya yang mendasari usahawan pendatang Bugis untuk melakukan usaha ekonomi demi keberlangsungan hidupnya dan keluarganya.

Sisi lain nilai dan norma yang melatari modal sosial dari usahawan pendatang Bugis adalah agama. Menunaikan ibadah ke tanah suci Mekah yang dimaknai sebagai bagian dari penyempurnaan ibadah telah menjadi motivasi tersendiri bagi usahawan Bugis dalam mengelola usaha. Keinginan dari usahawan pendatang Bugis untuk menunaikan ibadah haji juga memberikan semangat dalam melakukan usaha. Ini menunjukkan bahwa agama telah menjadi sumber spirit dalam berusaha. Oleh karena itu, pandangan Marx (Horton dan C.L. Hunt, 1999: 307) dengan konsep yang disebut sebagai kesadaran palsu yang ditujukan kepada agama tidaklah benar. Menurut Marx, agama yang menekankan kehidupan dunia akhirat dan harapan akan hidup sesudah mati menyebabkan orang menganggap penderitaan fisik di dunia ini akan mendapat pahala di kehidupan akhirat nanti, dapat memperlemah etos kerja masyarakat, justru berlaku sebaliknya. Falsafah hidup bagi usahawan pendatang Bugis dalam bentuk memperbaiki sikap, tutur kata, dan saling harga menghargai (sipakatau, sipakalebbi) antara sesama manusia, pesan-pesan leluhur, serta norma siri', dan motivasi agama telah menjadi sumber semangat atau spirit dalam melakukan usaha bagi usahawan pendatang Bugis di Kabupaten Takalar.

\section{SIMPULAN}

Keinginan untuk menunaikan ibadah haji dan mendapatkan penghargaan di masyarakat serta keinginan untuk mengejar status sosial merupakan nilai dan norma yang dianut oleh usahawan pendatang Bugis yang melatari modal sosial mereka. Sementara itu, usahawan pendatang Jawa, Bali, dan Cina, keinginan untuk memperbaiki hubungan yang harmonis dengan sesama manusia dengan konsep menanam budi menjadi sumber motivasi utama di balik modal sosial mereka. Demikian juga didorong oleh nilai untuk mengamankan kehidupan mereka di hari tua.

\section{DAPTAR PUSTAKA}

Abustam, M.I. 1989. Gerak Penduduk, Pembangunan, dan Perubahan Sosial. Kasus Tiga Komunitas Padi Sawah di Sulawesi Selatan. Jakarta: UI Press.

Adler, P \& S Kwon. 2000. Social Capital: The Good, The Bad and The Ugly. In E Lasser (ed). Knowledge and Social Capital: Fondations and Applications. Butterworth Heinemann.

Anh, T.T. 1984. Nilai Budaya Timur dan Barat. Jakarta: PT Gramedia.

Dasgupta, P. 1999. Economic Progress and the Ideal of Social Capital. In P. Dasgupta \& I Serageldin (Ed). Social Capital: A Multifaceted Perspective, The World Bank.

Horton, P.B. \& C.L. Hunt. 1999. Sosiologi. Alih Bahasa: Amiruddin Ram dan Tita Sobari. Edisi keenam. Jilid 1. Jakarta. Penerbit Erlangga.

Faisal, M. 2005. Studi tentang Mobilitas Penduduk Sementara di Kabupaten Selayar Propinsi Sulawesi Selatan. Tesis, UNM. Tidak diterbitkan.

Fukuyama, F. 1999. Social Capital and Civil Society. Institut Of Public Policy. George Mason. University.

-, 2000. Social Capital, Civil Society, and Development. Third World Quarterly, 22(1): 7-20.

, 2005. Trust: The Social Virtues and Creation of Prosperity. New York: Free Press.

----------, 2007. Trust: Kebajikan Sosial dan Penciptaan Kemakmuran. Jakarta. Qalam.

Granovetter, M. 1985. Economic Action and Social Strukture: The Problem of Embeddedness. American Journal of Sociology 91: 481-510.

Hasbullah, J, 2006. Social Capital, Menuju Keunggulan Budaya Manusia Indonesia, Jakarta: MRUnited Press. 
Heilbroner, R.L. 1994. Terbentuknya Masyarakat Ekonomi. Jakarta: Bumi Aksara.

Mantra, I.B. 1978: Mobilitas Penduduk dari Desa ke Kota, Yogyakarta; Pusat Penelitian dan Studi Kependudukan UGM.

Melalatoa, M.J. 1997. Sistem Budaya Indonesia, Jakarta: PT. Pamator.

Muspida, 2007. Modal Sosial Dalam Pengelolaan Hutan Kemiri Rakyat di Kabupaten Maros Sulawesi Selatan, Disertasi, Makassar: UNHAS.

Rivai, M. 2007. Modal Sosial Masyarakat Bugis di Perkampungan Nelayan Anetue-Kaca Kab. Soppeng. Disertasi, Makassar: Unhas.
Sukoco, I dan Muchyi, H.A. 2015. Ecopreneurship dalam Menumbuhkan Usaha Berwawasan Lingkungan pada Sentra Industri Penyamakan Kulit Sukaregang Kabupaten Garut. Jurnal. Sosiohumaniora. Vol. 17 no. 2.

Tantu, H, 1982. "Hubungan antara Desa dan Kota", dalam Mulyanto Sumardi dan Hans-Dieter Evers (ed), Sumber Pendapatan, Kebutuhan Pokok dan Prilaku Menyimpang, (hal 161266) Edisi Pertama. Jakarta: CV Rajawali.

Putnam, R.D. 2000. Bowling Alone: The Collapse and Revival of American Community. New York: Simon and Schuster. 